\title{
Genetic and environmental effects on twin pregnancy and length of reproduction in Thoroughbred mares
}

\begin{abstract}
Reproductive data of 1910 Thoroughbred mares from seven Polish studs were analyzed using linear animal model. The mares were born between 1929 and 1994. The frequency of multiple pregnancies was 3.5\% in this population. Fecundity (defined as ratio of number of progeny to number of pregnancies) and length of reproduction were recorded. Heritability estimates of fecundity and the number of pregnancies were 0.03 and 0.07 , respectively. Genetic correlation between these traits was -0.42 whereas phenotypic and environmental correlations were close to zero (-0.05 and -0.04, respectively). In general, genetic, phenotypic and environmental trends for fecundity and the number of pregnancies were non-negative. However, these annual effects are highly fluctuated. It may be attributed to the influence of some sires incorporated into population. Hence, a segregation of single locus can be hypothesised.
\end{abstract}

Key Words: twinning rate, thoroughbred horses, genetic parameters, genetic trends

\section{Zusammenfassung}

Titel der Arbeit: Genetische und Umweltwirkungen auf Zwillingsschwangerschaft und Fortpflanzungsdauer bei Vollblutstuten

Fortpflanzungsdaten von 1910 Vollblutstuten aus sieben polnischen Gestüten wurden mittels eines linearen Tiermodells analysiert. Die Stuten wurden zwischen 1929 und 1994 geboren. Die Häufigkeit von Mehrlingsträchtigkeiten der untersuchten Tierpopulation betrug 3,5 \%. Weiterhin wurde die Fruchtbarkeit definiert als das Verhältnis der Nachkommenzahl zur Anzahl der Trächtigkeiten sowie die Fortpflanzungsdauer erfasst. Die Heritabilitätsschätzungen für die Fruchtbarkeit und die Anzahl der Trächtigkeiten ergaben Werte von $h^{2}=0,03$ bzw. $h^{2}=0,07$. Die genetische Korrelation zwischen diesen Merkmalen lag bei $r_{g}=-0,42$ während die phänotypischen Korrelatonen und Umweltkorrelationen bei nahe Null lagen (-0,05 bzw. -0,04). Im allgemeinen waren die genetischen, phänotypischen und Umwelttrends bezüglich der Fruchtbarkeit und der Anzahl der Trächtigkeiten nicht negativ, der genetische Trend für die Anzahl Trächtigkeiten eher positiv. Die Trends unterlagen jedoch jährlichen Schwankungen, welche möglicherweise auf den Einfluss einzelner Hengste innerhalb der untersuchten Populationen zurückzuführen sind. Eine Unabhängigkeit der einzelnen Loci wird daher vermutet.

Schlüsselwörter: Zwillingshäufigkeit, Vollblutpferde, genetische Parameter, genetische Trends

\section{Introduction}

It has been known for a long time that twin pregnancies in Thoroughbred mares are more frequent than in other breeds of horses (PERKINS and GRIMMETT, 2001; ZWOLIŃSKI, 1980). In most cases multiple pregnancies end with miscarriages and stillbirths. If not, live foal twins have usually demonstrated lower performance values compared to single ones (GREENWOOD, 1999; KULISA et al., 1999; MORRIS and ALLEN, 2001). Moreover, heterosexual twin pregnancies may cause leukocyte chimerism (freemartinism) which may lead to sterility of the female (REJDUCH et al. 2000). By contrast to other livestock species multiple pregnancies in horse breeding are unfavorable.

A number of reports on twinning rates have been done in cattle population (see review of KARLSEN et al., 2000a). They reported positive genetic trends for twinning rate 
and suggested considerable relationships with traits under direct selection. An investigation conducted by PAWLAK et al. (2000) in the so-called half-blood horse population (in Poland) indicates a positive trend in twinning rate. On the other hand the trait is low heritable in cattle (VAN VLECK and GREGORY, 1996; KARLSEN et al., 2000b; JOHANSON et al., 2001). To our knowledge no heritability estimates of twinning rate in horses have been available.

The main aim of the study was to estimate the heritability of twinning rate as well as relationships between the occurrence of multiple pregnancies and the length of reproduction in Thoroughbred mares. Furthermore, genetic, phenotypic and environmental trends have been evaluated as well.

\section{Material}

The records of 1910 Thoroughbred mares born between 1929 and 1994 were extracted from the Polish Stud Book of Thoroughbred horses. Analysis covered 7 studs in Poland: Golejewko, Iwno, Kozienice, Moszna, Rzeczna, Strzegom and Widzów. Pedigree data included pedigree records of 158 stallions and 1926 mares. Data on single, twin and triple pregnancies were used. Changes in the number of mares over time are shown in Figure 1. The average inbreeding level of the population studied did not exceed $2 \%$. Hence, the effect was omitted in the statistical model. Two traits were analysed: fecundity (expressed as ratio of number of progeny to number of pregnancies per mare) and the number of pregnancies per mare during lifetime.

Brief statistical description of the traits is given in Table 1.

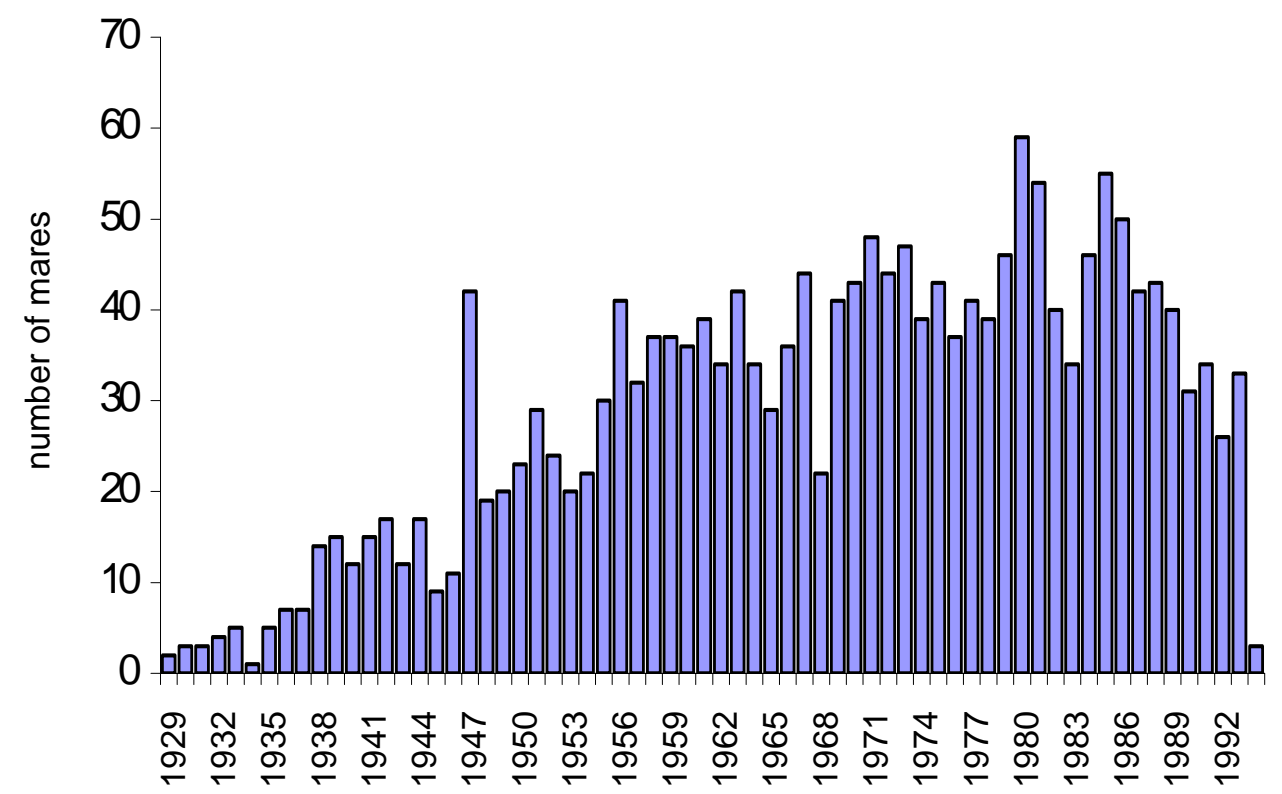

Fig. 1: Number of recorded mares in 1929-1994 (Anzahl der Stuten von 1929 bis 1994)

Table 1

Description of the data set (Beschreibung des Datensatzes)

\begin{tabular}{llll}
\hline Trait & $\begin{array}{l}\text { Average }^{1} \\
( \pm \text { SD) }\end{array}$ & $\begin{array}{l}\text { Average }^{2} \\
( \pm \text { SD })\end{array}$ & $\begin{array}{c}\text { Average }^{3} \\
( \pm \text { SD })\end{array}$ \\
\hline Number of pregnancies & 5.87906 & 6.48072 & 3.67168 \\
& \pm 3.47234 & \pm 3.51798 & \pm 2.12662 \\
Fecundity & 1.04313 & 1.04814 & 1.03024 \\
& \pm 0.24009 & \pm 0.10184 & \pm 0.12469 \\
\hline
\end{tabular}

1/ for $1929-1994 ;{ }^{2}$ / for $1929-1983 ;{ }^{3}$ / for $1984-1994$ 
Methods

The analysis was based on the below single trait linear model:

where:

$$
\mathbf{y}=\mathbf{X}_{1} \mathbf{b}_{1}+\mathbf{X}_{2} \mathbf{b}_{2}+\mathbf{Z a}+\mathbf{e}
$$

$\mathbf{y}$ is $1910 x 1$ vector of observations,

$\mathbf{b}_{1}$ is $66 \times 1$ vector of birth year effects,

$\mathbf{b}_{2}$ is $7 \times 1$ vector of stud effects,

a is $2084 x 1$ vector of additive genetic effects,

e is $1910 \times 1$ vector of random errors,

$\mathbf{X}_{\mathbf{1}}$ is 1910x66 incidence matrix for year effects,

$\mathbf{X}_{\mathbf{2}}$ is $1910 \times 7$ incidence matrix for stud effects,

$\mathbf{Z}$ is $1910 x 2084$ incidence matrix for genetic effects.

The model holds on the following assumptions:

$$
\operatorname{var}(\mathbf{a})=\mathbf{A} \sigma_{a}^{2}, \operatorname{var}(\mathbf{e})=\mathbf{I} \sigma_{e}^{2}, \operatorname{cov}(\mathbf{a}, \mathbf{e})=\mathbf{0}
$$

and $\mathbf{y} \sim \mathrm{N}\left(\mathbf{X}_{\mathbf{1}} \mathbf{b}_{\mathbf{1}}+\mathbf{X}_{\mathbf{2}} \mathbf{b}_{\mathbf{2}}, \mathbf{Z A Z} \boldsymbol{Z}_{a}^{2}+\mathbf{I} \sigma_{e}^{2}\right)$.

The following genetic parameters were estimated:

- heritabilities of fecundity and number of pregnancies

- genetic, phenotypic and environmental correlation between fecundity and the number of pregnancies

- genetic, phenotypic and environmental trends

As already mentioned, a number of years has been studied. Hence, the heritability was estimated both for full data file and sub-data files formed according to birth years of mares (DATA1 - until 1983; DATA2 -since 1984)

Correlation coefficient estimates were also obtained on the basis of the single trait linear model according to the formulae described by SEARLE and ROUSVILLE (1974):

$$
\sigma_{(u+w)}^{2}=\sigma_{u}^{2}+\sigma_{w}^{2}+2 \sigma_{u w}
$$

Thus: $\sigma_{u w}=0.5\left(\sigma_{(u+w)}^{2}-\sigma_{u}^{2}-\sigma_{w}^{2}\right)$.

Then the correlation coefficient $(\rho)$ is defined as follows:

$$
\rho=\frac{\sigma_{u w}}{\sigma_{u} \sigma_{w}}
$$

where: $\sigma_{u w}$ is the covariance (phenotypic, genetic and residual) between traits, $\sigma_{u}$ and $\sigma_{w}$ are standard deviations (phenotypic, genetic and residual) for traits $u$ and $w$, respectively.

Genetic trends were derived as prediction of annual addition genetic effect (BLUP). Environmental trends were based on estimate of year effects taken from a solution of mixed model equations, whereas phenotypic trends were established as annual trait means.

These computations were performed by the use of derivative free restricted maximum likelihood (DFREML) package programs (MEYER, 2001).

\section{Results}

The study covered 11229 pregnancies (including 391 multiple pregnancies). Only two foals were triplets, the rest were twins. Generally, frequency of multiple pregnancies was 3.5\%. 262 (82.1\%) mares had twinned once, 52 (16.3 \%) twinned twice, 2 (0.6\%) 
twinned a third time, $2(0.6 \%)$ twinned a fourth time and $1(0.3 \%)$ twinned a sixth time. In general the phenotypic trend for fecundity (Fig. 2) are very moderate. The trend shows three visible high fluctuations in 1934, 1953 and 1970.

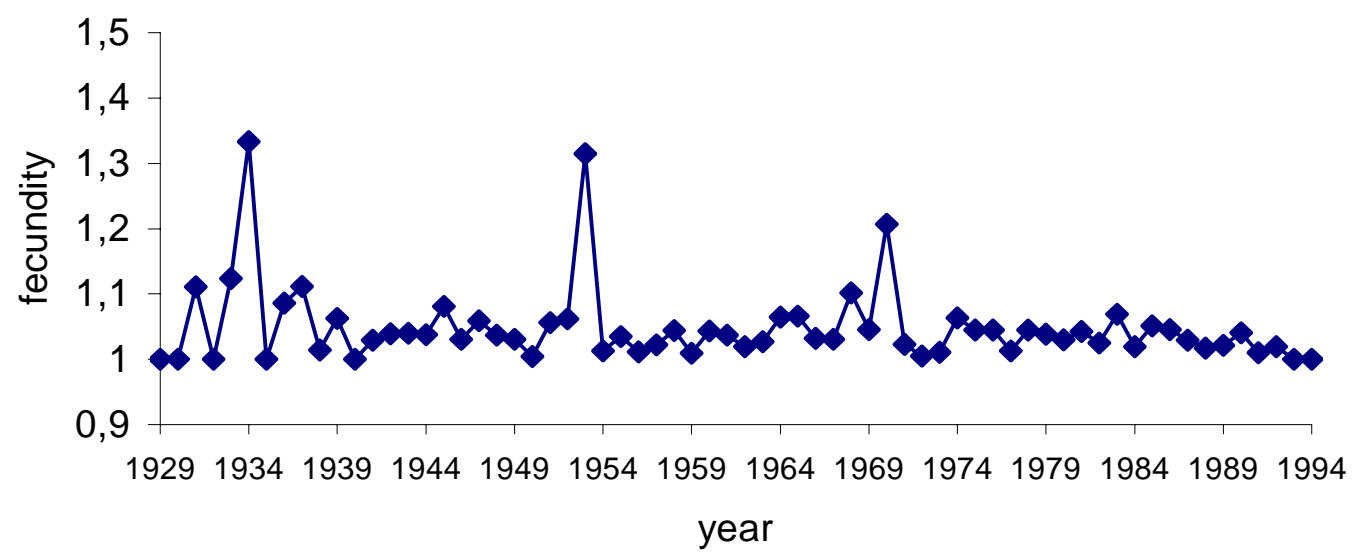

Fig. 2: Phenotypic trend for fecundity (Phänotypischer Trend für Fruchtbarkeit)

The phenotypic trends for number of pregnancies (Fig. 3) is highly changeable. However, the negative trend since the 1980's is partially affected by current performed mares. By the way, it should be noted that in recent years, mares have been diagnosed on multiple ovulation. In case positive results, one of the fetuses is sacrificed or the mare is culled. Hence, registration of twins is limited by length of reproduction.

Table 2 shows heritability estimates and their standard deviations of fecundity and the number of pregnancies. As expected, these estimates are very low. However, in case both traits these heritabilities are negligible higher for first period compared to second one. It seems that the differences are mainly influenced by number of mares analysed within the period studied. Furthermore, it can be affected by correlated response of selection as well.

Estimates of genetic, phenotypic and environmental correlations between fecundity and the number of pregnancies are listed in Table 3 . The genetic correlation estimate was -0.418 , whereas phenotypic and environmental effects were close to zero $(-0.049$ and -0.035 , respectively). Negligible phenotypic and environmental correlation coefficients exhibited genetic backgrounds of culling decision as well.

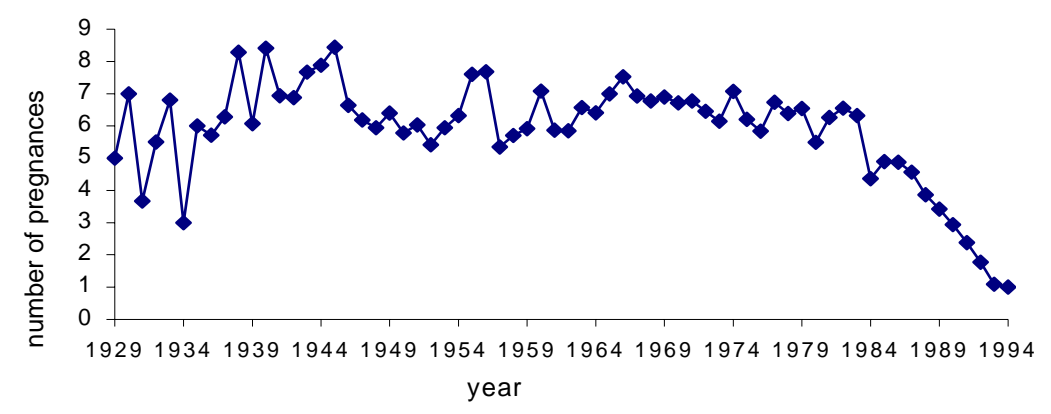

Fig. 3.: Phenotypic trend for number of pregnancies (Phänotypischer Trend für Anzahl der Trächtigkeiten) 
Table 2

Estimates of heritability of traits studied and their standard deviations (Schätzungen von Erblichkeit und Standardabweichungen der untersuchten Merkmale)

\begin{tabular}{lccc}
\hline Trait & DATA1 & DATA2 & Total \\
\hline Number of pregnancies & 0.079 & 0.053 & 0.069 \\
& \pm 0.029 & \pm 0.024 & \pm 0.026 \\
Fecundity & & & \\
& 0.028 & 0.021 & 0.024 \\
\hline Non & \pm 0.017 & \pm 0.016 & \pm 0.016 \\
\hline
\end{tabular}

Note on symbols: DATA1 for 1929-1983; DATA2 for 1984-1994

Table 3

Estimates of genetic, phenotypic and environmental correlations between fecundity and the number of pregnancies and standard deviations (Schätzungen der genetischen, phänotypischen und Umweltkorrelationen zwischen Fruchtbarkeit und Anzahl der Trächtigkeiten und Standardabweichungen)

\begin{tabular}{lcc}
\hline Correlation & Estimate & Standard deviation \\
\hline Genetic & -0.418 & \pm 0.019 \\
Phenotypic & -0.049 & \pm 0.023 \\
Environmental & -0.035 & \pm 0.023 \\
\hline
\end{tabular}

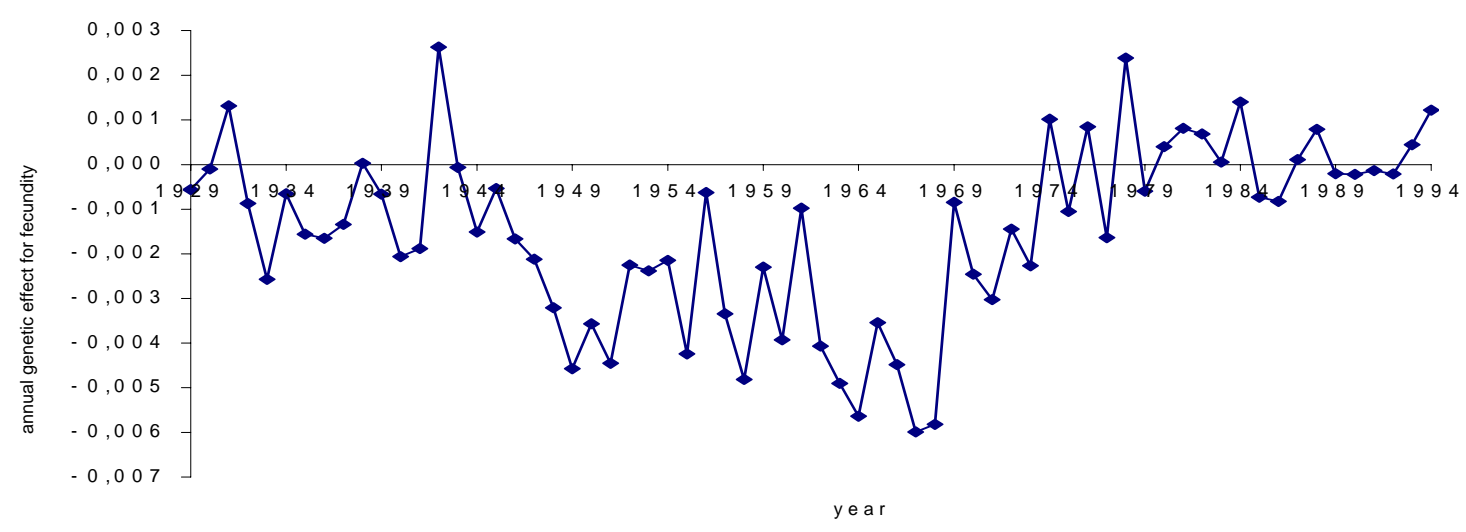

Fig. 4: Genetic trend for fecundity (Genetischer Trend für Fruchtbarkeit)

Genetic trends for the fecundity and number of pregnancies are presented in Figures 4 and 5. When first and last years are compared the difference in annual genetic effects for fecundity is positive. Over the time studied, the average breeding values are fluctuated. However since the 1960's the trend is quite positive. By the way, it should be recalled that the definition of fecundity considered in this study does not include the total number of offspring per dam. The genetic trend for a second trait is negligible. Although as in the case of fecundity, since the 1960's the annual genetic value tends to increase. It is likely to be connected with the incorporation of foreign stallions for reproduction in the population studied. Moreover, thoroughbred horses are the fastest horses in the world and selection for this trait has been conducted for long time. Let us recall, that the heritabilities of both traits studied are very low. It implies considerable changes of the annual environmental (year) effects. These trends are presented in 
Figures 6 and 7. In general, the shapes of the trend curves are similar to the phenotypic ones.

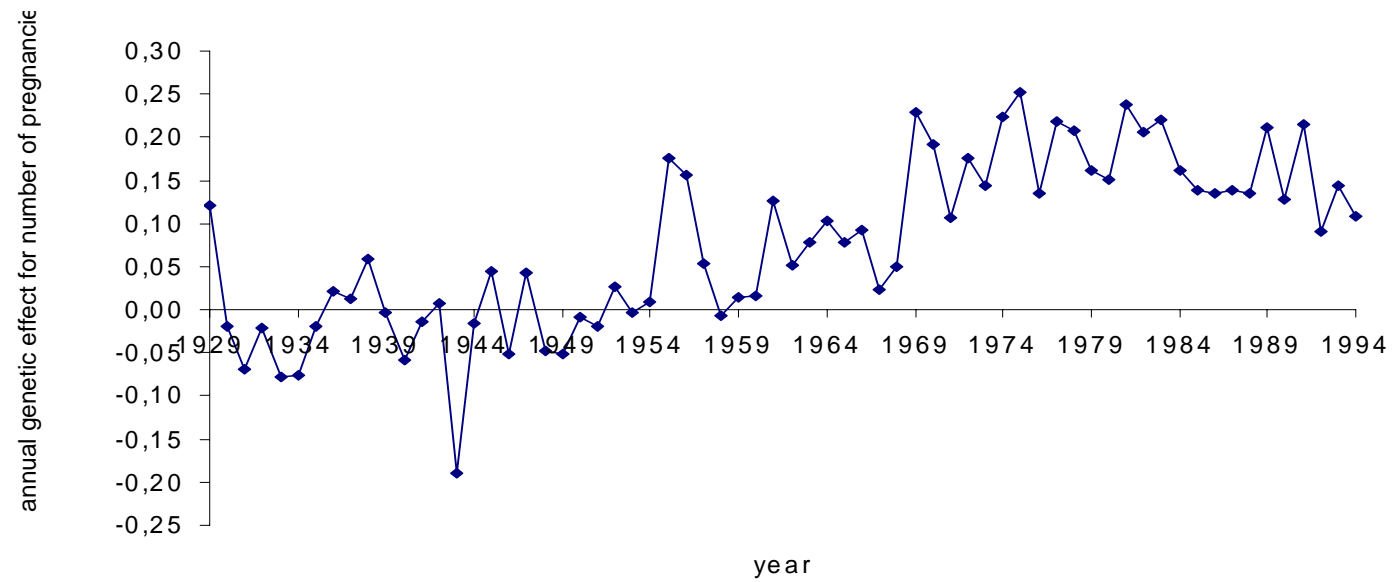

Fig. 5: Genetic trend for number of pregnancies (Genetischer Trend für Anzahl der Trächtigkeiten)

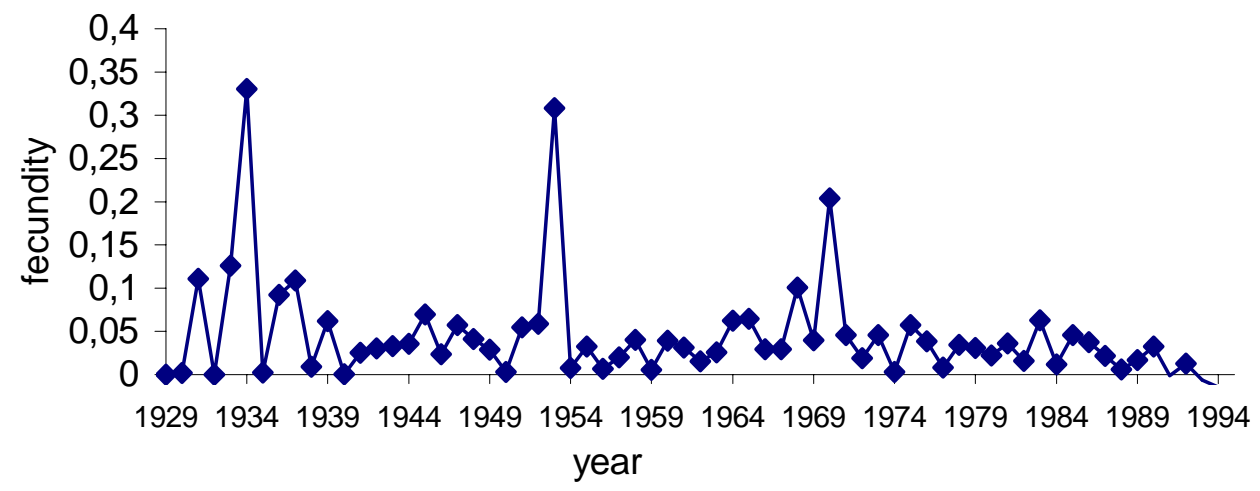

Fig. 6: Environmental trend for fecundity (Umwelttrend für Fruchtbarkeit)

\section{Discussion}

In general, the estimated frequency of multiple pregnancies corresponds with results obtained by other authors (PAWLAK et al., 2000). As it already mentioned, the trend shows visible high fluctuations. It seems that it is connected with the incorporation of some stallions into the population. The suggestion corresponds with results obtained by WACHOWSKA (unpublished data) who reported very high frequencies of twinning in some families in this population. Detailed analysis of pedigree showed that some stallions can be classified into two opposite groups according to twinning level of their daughters. For instance, one stallion had 7 daughters and 5 of them had twin pregnancies, whereas an analysis of the pedigree of mares mated with this stallion did 
not show any ancestors with the occurrence of multiple pregnancies. The top stallion had 24 daughters with multiple births. Mixed inheritance model of this trait has been also hypothesised by ZOLDAG et al. (2001). Studies on cattle showed similar conclusions. Some bulls had several hundred daughters with no multiple births, and the top bull had daughters with a twinning rate of 12.9\% (KARLSEN et al., 2000b).

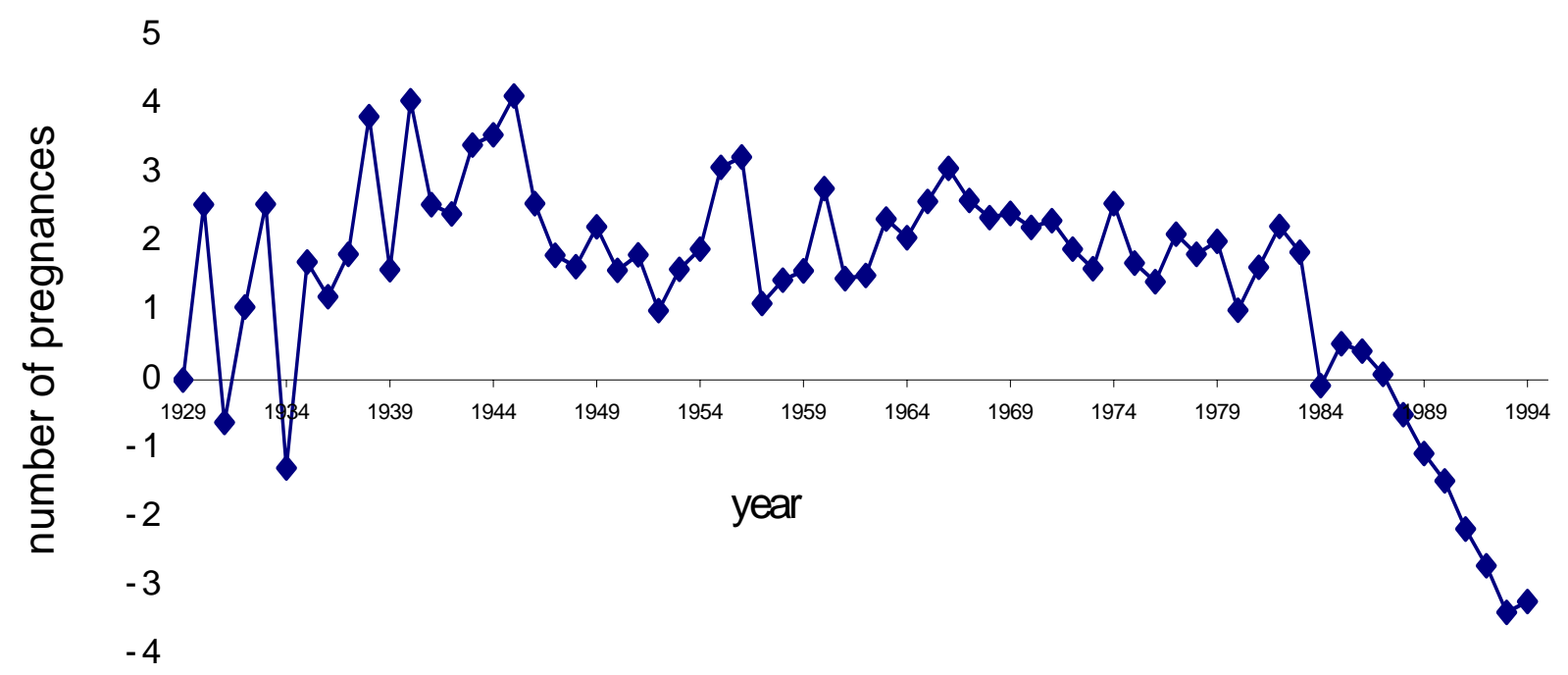

Fig. 7: Environmental trend for number of pregnancies (Umwelttrend für Anzahl der Trächtigkeiten)

From a theoretical perspective low heritability estimates can indicate a larger environmental influence compared to genetic ones. It is well known that reproductive traits are lowly heritable. It is in agreement with a number of reports performed first of all in the twinning rate of cattle (KARLSEN, 2000b). On the other hand, VAN VLECK and GREGORY (1996) showed that in cattle selection increased the average twining rate from $3.4 \%$ to $28.5 \%$ in fifteen years.

In general, these traits are troublesome in statistical modelling. One of the main assumptions of the classical methods is, among others, normality of residuals. Unfortunately, these traits do not hold the assumption. Both the number of progenies per pregnancy, and the number of pregnancies are typical discrete traits determined by many loci. But the twinning rate may also be expressed as a continuous trait (when it is summarised as fecundity). These heritabilities of the traits can be underestimated since in case of a deviation from the model assumption, the error variance is overestimated. VAN TASSEL et al. (1998) and JOHANSON et al. (2001) reported higher heritability estimates from the threshold than linear model for twinning cattle data, whereas KADARMIDEEN et al. (2000) obtained very close estimates via both types of models. In spite of all, further analysis should be based on the threshold model.

These results obtained clearly indicate that twinning is influenced by reproductive ability of dams. GREGORY et al. (1996) showed that greater dystocia and lower survival of progeny are the major constraints to twinning technology in dairy and beef cattle. Negligible phenotypic and environmental correlation coefficients exhibited genetic backgrounds of culling decision as well. 
The positive genetic trends may be associated with applied direct selection since the 1960's. Such tendencies have been observed in cattle. For instance, MAIJALA and OSVA (1990) found a positive genetic correlation between the twinning rate and milk yield. The shapes of the trends curve are similar to the phenotypic ones.

Investigations carried out in cattle indicate some environmental factors affecting the twinning rate. KARLSEN et al. (2000a) reviewed that cattle fecundity can be influenced by parity, age at calving, season of calving as well as nutrition. The season effect is very important because of the length of daylight and temperature, which affects the rate of multiple ovulation. An analysis showed that the occurrence of multiple pregnancies was higher for 5-10 year old mares (WACHOWSKA, unpublished data). Moreover, the studies performed in humans indicate drugs to control fertility as stimulants of twinning rate. It seems that these factors can affect the changes in fecundity in this population. However, on the basis of preliminary pedigree analysis given by WACHOWSKA (unpublished data) the three peaks of environmental effects are probably overestimated by some sires.

\section{Some implications}

Although heritability estimates for both fecundity and number of pregnancies are low, it seems that they are affected by some deviation from the assumption of the model employed (e.g. skewed distribution). In general, genetic, phenotypic and environmental trends for fecundity and the number of pregnancies were non-negative. However, these annual effects are very fluctuated (three annual peaks of multiple births were registered). It may be due to the influence by some sires incorporated into the population. Hence, a segregation of single locus can be hypothesised.

\section{Acknowledgments}

The authors are grateful to Dr. Karin Meyer for supplying a set of DFREML programs.

GREENWOOD, R.E.S.:

\section{References}

The occurrence and successful veterinary management of twinning in the thoroughbred mare. Pferdeheilkunde 15 (1999) 6, 603

GREGORY, K.E.; ECHTERNKAMP, S.E.; CUNDIFF, L.V.:

Effects of twinning on dystocia, calf survival, calf growth, carcass traits, and cow productivity. J. Anim. Sci. 74 (1996), 1223-1233

JOHANSON, J.M.; BERGER, P.J.; KIRKPATRICK, W.; DENTINE, M.R.:

Twinning rates for North American Holstein sires. J. Dairy Sci. 84 (2001), 2081-2088

KADARMIDEEN, H.N.; THOMPSON, R.; SIMM, G.:

Linear and threshold model genetic parameters for disease, fertility and milk production in dairy cattle. Anim. Sci. 71 (2000), 411-419

KARLSEN, A.; KLEMENTSDAL, G.; RUANE, J.:

Twinning in Cattle. Anim. Breed. Abstr. 68 (2000a), 1, 1-8

KARLSEN, A.; RUANE, J.; KLEMENTSDAL, G.; HERINGSTAD, B.:

Twinning rate in Norwegian cattle: Frequency, (co)variance components and genetic trends. J. Anim. Sci. 78 (2000b), 15-20

KULISA, M.; PIESZKA, M.; FRYBES, O.:

Multiple pregnancies in Thoroughbred horses breeding in Poland in 1987-96 years. Medycyna Weterynaryjna 55 (1999), 869-693 (in Polish, with English summary)

MAIJALA, K.; OSVA, A.: Genetic correlations of twinning frequency with other economic traits in dairy cattle, J. Anim. Breed. Genet. 107 (1990), 7-15

MEUWISSEN, T.H.E.; KARLSEN, A.; LIEN, S.; OLSAKER, I.; GODDARD, M. M. E.: 
Fine mapping of a quantitative trait locus for twinning rate using combined linkage and linkage MEYER, K.: disequilibrim mapping. Genetics 161 (2002), 373-379

Programs to estimate variance components for individual animal models by restricted maximum likelihood (REML) ver. 3.1.0. User notes. Institute of Animal Science, Armidale, Australia, 2001

MORRIS, L.H:A.; ALLEN, W.R.:

Reproductive efficiency of intensively managed Thoroughbred mares in Newmarket. Equine Veter. J. 34 (2001), 51-60

PAWLAK, M.; TORZYŃSKI, G.; ŚWITOŃSKI, M.:

Increase of the frequency of twin pregnancies in Thoroughbred and half-blood mares bred in Poland. Anim. Sci. Pap. Rep. 18 (2000), 157-163

PERKINS, N.R.; GRIMMETT, J.B.:

Pregnancy and twinning rates in thoroughbred mares following the administration of human chorionic gonadotropin (hCG). New Zealand Veter. J. 49 (2001) 3, 94-100

REJDUCH, B.; SŁOTA, E.; GUSTAVSSON, I.:

$60, \mathrm{XY} / 60, \mathrm{XX}$ chimerism in the germ cell line of mature bulls born in heterosexual twinning. Theriogenology 54 (2000) 4, 621-627

SEARLE, S.R.; ROUSVILLE , T.R.:

A note on estimating covariance components. Americ. Stat. 28 (1974), 67-68

VAN TASSELL, C.P.; VAN VLECK, L.D.; GREGORY, K.E.:

Bayesian analysis of twinning and ovulation rates using a multiple-trait threshold model and Gibbs sampling, J. Anim. Sci. 76 (1998), 2048-2060

VAN VLECK, L.D.; GREGORY, K.E.:

Variances of additive and dominance genetic effects for ovulation and twinning rates in a population selected for twinning. J. Anim. Sci. 74 (1996), 1234-1239

ZOLDAG, L.; PARTALI, C.; ESZES, F.:

Importance of twinning in horse breeding. Magyar Allatorvosok Lapja 6 (2001), 360-365 (in Hungarian, with English summary)

ZWOLINSKI, J.:

Horse breeding PWRiL, Warszawa 1980 (in Polish)

Received: 2003-07-03

Accepted: 2004-02-26

Author's addresses

Ms. ANNA BRESINSKA

Department of Genetics and Animal Breeding

August Cieszkowski Agricultural University of Poznan

Wolynska str. 33

PL60-637 Poznan / Poland

Ms. LAURA WACHOWSKA

Department of Genetics and Animal Breeding

August Cieszkowski Agricultural University of Poznan

Wolynska str. 33

PL60-637 Poznan / Poland

Prof. Dr. TOMASZ SZWACZKOWSKI - corresponding author

Department of Genetics and Animal Breeding

August Cieszkowski Agricultural University of Poznan

Wolynska str. 33

PL60-637 Poznan / Poland

e-mail: tomasz@jay.au.poznan.pl 